\title{
Effect of Xanthohumol Added to Diet on Blood Biochemistry in Japanese Quails
}

\author{
Zuzana Lacková $^{1 *}$, František Zigo ${ }^{2}$ and Zuzana Farkašováa ${ }^{3}$ \\ ${ }^{1}$ Department of Nutrition and Animal Husbandry, University of Veterinary Medicine and Pharmacy \\ Košice, Slovakia \\ *Corresponding author's mail: zuzana.lackova [AT] uvlf.sk \\ ${ }^{2}$ Department of Nutrition and Animal Husbandry, University of Veterinary Medicine and Pharmacy \\ Košice, Slovakia \\ Email: frantisek.zigo [AT] uvlf.sk \\ ${ }^{3}$ Department of Nutrition and Animal Husbandry, University of Veterinary Medicine and Pharmacy \\ Košice, Slovakia \\ Email: zuzana.farkasova [AT] uvlf.sk
}

\begin{abstract}
In this paper, we monitored to effect of xanthohumol added to diet on blood biochemistry in Japanese quails. Forty Japanese quails breeds lines Pharaoh were included in the experiment. The quails were randomly divided into two groups: one control and one experimental group with supplementation by xanthohumol in feed. In the evaluation of biochemical parameters, we focused on total protein, albumin, globulin, glucose, cholesterol and enzyme activity of AST (Aspartate aminotransferase), ALT (Alanine aminotransferase) and $r$-GT (rGlutamyltransferase). Statistical comparisons were made between group with supplementation by xanthohumol in feed and the control group. Total protein and albumin levels were significantly differed between groups $(P<0.05)$. A significant decrease in AST activity $(P<0.05)$ was observed in supplementation group relative to control group.
\end{abstract}

Keywords - xanthohumol, supplementation, Japanese quail, blood biochemistry

\section{INTRODUCTION}

Hops have for a long time been used for various medical purposes [1]. Hops are also rich sources of flavone glycosides and condensed tannins. Prenylated flavonoids are one kind of bioactive substances contributing to its medical applications. The most abundant prenylated flavonoid in hops is xanthohumol (Xn; 3'-[3,3-dimethylallyl]-2',4',4trihydroxy-6'-methoxychalcone). The distribution of xanthohumol is limited to and ubiquitous within Humulus lupulus. In nature, xanthohumol exists ubiquitously within hops plant, with a content of $0.1 \%-1 \%$ (dry weight) in the female inflorescences [2]. This polyphenol can be included in the diet through foods in which hops are used, such as beer or food supplements. Xanthohumol in particular, has attracted the attention of the scientists, thanks to is biological effects. Lab studies have shown positive results from xanthohumol as a dietary supplement $[3,4,5]$. The beneficial pharmacological properties of Xanthohumol were not appreciated until 1990s, including antioxidant, anti-inflammatory, antibacterial, antiviral, antifungal, and antiplasmodial activity [6].

Quail farming is not a very popular branch of poultry farming, yet it comprises a worthy niche with respect to the diversity of retail products. The wide variety of breeds, lines and crosses of Japanese quails for fattening, often from different productive types, requires using various approaches in fattening technologies. In recent years, the addition of different organic dietary sources has become an inherent practice in poultry production. Not only as they represent a source of energy but also the beneficial content of improving the growth and quality of meat. The preference for the Japanese quail is justified by the fact that it is well adapted to laboratory conditions and possesses several advantages, such as rapid growth, early sexual maturity, high rate of egg production, easy handling of adult size, and a short generation interval [7].

Japanese quail (Coturnix coturnix japonica) is a poultry species that is reared mainly for eggs and meat. Intensive production systems where birds are kept on litter in confined spaces contribute to the spread infections [8]. A wide range of the blood biochemistry and its relationship to poultry species performance has been reported in literature. For those species used as poultry, blood chemistry was established to some extent for quail [9], chicken [10, 11], duck [12], turkey [13] and ostrich [14]. 
Japanese quails are small and highly mobile birds; therefore, blood sampling is technically difficult and requires sacrifice [8]. The blood biochemical analysis is a valuable tool for evaluating the health of animal and helps both in diagnosis and clinical monitoring of disease. Its evaluation indicates the extent of damage in various vital organs and status of the disease. Serum biochemical profiling has been used in several species of domestic livestock to monitor herd health and to detect subclinical disease. Hematological and biochemical status is a reflection of many factors such as sex, age, breed, diet, management and stress level $[15,16]$.

In the present study was monitored the effect of xanthohumol added to diet on blood biochemistry of Japanese quail.

\section{MATERIAL AND METHODOLOGY}

\subsection{Experimental groups and supplementation}

Forty Japanese quails breeds lines Pharaoh (Farm Mala Ida s.r.o., Slovak Republic) were included in the experiment. The quails were randomly divided into two groups: one control and one experimental group. The formed groups of quails were housed in cage boxes $(1.5 \times 1.5 \mathrm{~m})$ lined with $5 \mathrm{~cm}$ litter of sawdust and straw. All groups were fed with complete feed for quail MINI in the size of granules 1-3 mm (producer De Heus a.s., CZ). The access to water and feed was ad libitum. The experimental group diets were supplemented by xanthohumol.

The feed dose consisted of wheat, maize, vegetable oil and fat (sunflower seed), soya extracted scrap, distillery dark draff, extracted scrap of shelled sunflower seed, calcium carbonate, wheat germ, fishmeal, monocalcium phosphate, sodium chloride. Additives added to feed intended for the feeding of Japanese quail are as follows: vitamin A, vitamin D3, vitamin E, copper sulphate, zinc sulphate, Zn, Fe, Se, I, manganese oxide, ferrous sulphate, sodium selenite, calcium iodate. The content of analytical constituents in feed is as follows: crude protein $23.6 \%$, oils and fats $3.4 \%$, fiber $3.5 \%$, ash $8 \%$, lysine $1.41 \%$, methionine $0.56 \%$, calcium $1.5 \%$, phosphorus $0.86 \%$, sodium $0.14 \%$.

Feed supplementation by xanthohumol, has been administered for 52 days, from the 8th day of quail age. After completion of supplementation, quails aged 60 days were killed by decapitation [17].

\subsection{The processing of hop extracts}

Hop extract containing $75 \%$ xanthohumol has been used in monitoring. This extract has been processed at a higher temperature with KOLLIDON VA64 to improve its water solubility and bioavailability (EP171766458.4). The used extrudate contained $10 \%$ xanthohumol extract.

\subsection{Blood analyses}

Blood samples were collected by rapid decapitation into tubes. The time between removing the birds from cages and blood sampling was 20 seconds. Blood samples were centrifuged at $2500 \mathrm{x} \mathrm{g}$ for 10 minutes.

Biochemical analyses of glucose (GLU), cholesterol (CHOL), total protein (TP) and were tested by the use of automatic analyzer Unicel DxC 880i (Beckman Coulter, USA) using the commercial kits Labtest according to the methods described by Duncan et al. [18].

Determination of aspartate aminotransferase (AST), alanine transaminase (ALT), and $\gamma$-Glutamyltransferase $(\gamma$-GT) was based on the absorbance measurement. The concentration of these enzymes was determined spectrophotometrically [19]. For all spectrophotometric methods, Cobas C111 biochemistry analyzer (Roche diagnostics Ltd., Basel, Switzerland) was used.

\subsection{Statistical analysis}

Statistical processing and evaluation of the results were performed in Microsoft Excel. The results of the statistical analyses are given in tables such as mean (M) and standard deviation (SD). The significance of the differences in the mean values between the supplemented and control group was tested by t-test on the significance level of 0.05 .

\section{RESULTS AND DISCUSSION}

Evaluation of the blood and serum biochemistry profile of quails provide useful information about their physical condition, making them useful tools in differentiating apparently healthy birds from abnormal or diseased ones [20]. The results of biochemical estimation are given in Table 1 . When the results of this study were compared with reference values of Scholtz et al. [21], decreases in the AST, ALT and $\gamma$-GT values were observed, while the total proteins, globulin; albumin levels are similar to those obtained by Prakash [22]. There was evidence for sex-related differences in several biochemical parameters. The AST, ALT, glucose and bilirubin values were higher in males, whereas the female birds had higher values of albumin, total protein, $\gamma$-GT, total cholesterol, and [21]. Several sex-related differences may be explained by the physiological changes in metabolism in female birds due to egg laying: during the laying period, the 
hepatic synthesis of triglycerides, phospholipids, and cholesterol is increased [23]. Laying hens therefore have extraordinarily high circulating concentrations of triglycerides and cholesterol in contrast to male birds [24].

Total protein and albumin levels differed significantly between groups $(P<0.05)$, but remained within the reference ranges. We determined increases in levels of total protein, albumin and globulin in the quail from the supplement group. Avian total protein consists mainly of albumin and $\alpha-, \beta$-, and $\gamma$-globulin [25]; thus, elevated concentrations of total protein in egg-laying birds are accompanied by significant increases in levels of serum albumin and globulin [26]. Sokól et al. [8] reported that in all groups of quails the values of TP, albumin, cholesterol, and ALT activity were within the normal range, except AST activity which was lower in all examined birds. The serum cholesterol content increased in Japanese quails. In other studies on variation in egg performance and plasma constituents at different ages of female Japanese quails observed a gradual increase in cholesterol level with age and the highest value was observed at 30 weeks of age while the lowest value was observed at 8 weeks of age [27]. The serum contents of cholesterol, albumin, total protein, globulin, uric acid, and calcium of Japanese quail were increased with age [16, 23]. We determined decreases in level of glucose. The decrease in the serum glucose level may be due increased secretion of steroid hormones with age of the birds for the preparation of laying [16].

Table 1: The selected serum biochemical parameters in blood of Japanese quails after supplementation to diet by xanthohumol

\begin{tabular}{|c|c|c|c|c|}
\hline Parameters & Unit & Xn-diet group & Control group & $\begin{array}{c}\text { Reference values of } \\
\text { Scholtz et al. [21] }\end{array}$ \\
\hline $\begin{array}{c}\text { Total protein (TP) } \\
\text { Albumin } \\
\text { Globulin } \\
\text { Glucose (GLU) } \\
\text { Cholesterol (CHOL) } \\
\text { Aspartate } \\
\text { aminotransferase (AST) } \\
\text { Alanine } \\
\text { aminotransferase (ALT) } \\
\text { Г-Glutamyltransferase } \\
(\gamma-\mathrm{GT})\end{array}$ & $\begin{array}{c}\mathrm{g} / \mathrm{l} \\
\mathrm{g} / \mathrm{l} \\
\mathrm{g} / \mathrm{l} \\
\mathrm{mmol} / \mathrm{l} \\
\mathrm{mmol} / \mathrm{l} \\
\mu \mathrm{kat} / \mathrm{l} \\
\mu \mathrm{kat} / \mathrm{l} \\
\mu \mathrm{kat} / \mathrm{l}\end{array}$ & $\begin{array}{c}34.5 \pm 2.7^{\mathrm{a}} \\
13.2 \pm 1.1^{\mathrm{a}} \\
21.3 \pm 3.3 \\
15.81 \pm 1.66 \\
4.68 \pm 0.81 \\
3.94 \pm 0.72^{\mathrm{a}} \\
0.05 \pm 0.01 \\
0.01 \pm 0.01\end{array}$ & $\begin{array}{c}30.3 \pm 2.3^{\mathrm{b}} \\
11.2 \pm 0.87^{\mathrm{b}} \\
19.1 \pm 3.5 \\
16.30 \pm 1.92 \\
4.35 \pm 0.72 \\
4.90 \pm 0.76^{\mathrm{b}} \\
0.06 \pm 0.01 \\
0.02 \pm 0.02\end{array}$ & $\begin{array}{c}29.7-43.3 \\
12.5-18.0 \\
- \\
7.5-21.3 \\
4.1-9.9 \\
- \\
- \\
-\end{array}$ \\
\hline
\end{tabular}

Note: $\mathrm{Xn}$ - xanthohumol; Results are presented as mean $\pm \mathrm{SD}$; ${ }^{\mathrm{a}, \mathrm{b}}$ - values above the columns sharing different letters are significantly different $(P<0.05)$.

A significant decrease in AST activity $(P<0.05)$ was observed in supplementation group relative to control group. Aspartate aminotransferase is often associated with liver parenchymal cells but is also present in red blood cells and cardiac and skeletal muscle. Significant elevations in bird AST concentrations would be indicative of hepatocellular disease [28, 29]. Sex-related differences are also observed for $\gamma$-GT. High levels of serum $\gamma$-GT are commonly used as an index of liver disease, as well as damages in biliary ducts and renal epithelium [30], but it also increases in female birds, apparently reflecting increased liver metabolism due to egg laying [31]. Like $\gamma$-GT, AST enzymes are involved in the transamination of glycogenic amino acids to produce glucose [30]. Regarding ALT, significantly higher activities were found in female curls compared to with males [32].

\section{CONCLUSION}

We determined increase in levels of total protein $(P<0.05)$, albumin $(P<0.05)$, globulin and cholesterol in the quails from the supplement group. On the other hand, the addition of xantohumol decreased the values of AST, ALT and $\gamma$-GT. A significant decrease in aspartate aminotransferase (AST) activity $(P<0.05)$ was observed in the supplemented group.

\section{ACKNOWLEDGEMENT}

This work was supported by the project KEGA no. 006UVLF-4-2020.

\section{REFERENCES}

[1] Zanoli, P., Zavatti, M. "Pharmacognostic and pharmacological profile of Humulus lupulus L" Journal of Etnopharmacology. vol. 116, no. 3, pp. 383-396, 2008. 
[2] Chen Q. H., Fu M. L., Chen M. M., Liu J., Liu X. J., He G. Q., et al. "Preparative isolation and purification of xanthohumol from hops (Humulus lupulus L.) by high-speed counter-current chromatography", Food Chemistry. vol. 132, no. 1, pp. 619-623, 2012.

[3] Zamzow, D. R., Elias, V., Legette, L. L., Choi, J., Stevens, J. F., and Magnusson, K. R. "Xanthohumol improved cognitive flexibility in young mice", Behavioural Brain Research. vol. 275, pp. 1-10, 2014.

[4] Miranda, C. L., Elias, V. D., Hay, J. J., Choi, J., Reed, R. L., and Stevens, J. F. "Xanthohumol improves dysfunctional glucose and lipid metabolism in diet-induced obese C57BL/6J mice." Archives of Biochemistry and Biophysics. vol. 599, pp. 22-30, 2016.

[5] Stevens, J. F., \& Page, J. E. "Xanthohumol and related prenylflavonoids from hops and beer: to your good health!" Phytochemistry. vol. 65, no.10, pp. 1317-1330, 2004.

[6] Liu, M., Hansen, P. E., Wang, G., Qiu, L., Dong, J., Yin, H., et al. "Pharmacological profile of xanthohumol, a prenylated flavonoid from hops (Humulus lupulus)", Molecules. vol. 20, no. 1, pp. 754-779, 2015.

[7] Ichilcik, R. and Austin, J. C. „The Japanese quail (Coturnix coturnix japonica) as a laboratory animal“, Journal of the South African Veterinary Association. vol. 49, no. 3, pp. 203-207, 1978.

[8] Sokół, R., Gesek, M., Raś-Noryńska, M., Michalczyk, M., Koziatek, S. "Biochemical parameters in Japanese quails Coturnix coturnix japonica infected with coccidia and treated with Toltrazuril”, Polish Journal of Veterinary Sciences. vol. 18, no. 1, pp. 79-82, 2015.

[9] Faqi, A. S., R. Solecki, R. Pfeil, and V. Hilbig. „Standard values for reproductive and clinical chemistry parameters of Japanese quail“, Deutsche Tierärztliche Wochenschrift. vol. 104, no. 5, pp. 167-169, 1997.

[10] Ross, J. G., G. Christie, W. G. Halliday, and R. M. Jones. „Determination of haematology and blood chemistry values in healthy six-week old broiler hybrids“, Avian Pathology. vol. 5, no. 4, pp. 273-281, 1976.

[11] Ross, J. G., G. Christie, W. G. Halliday, and R. M. Jones. "Haematological and blood chemistry "comparison values" for clinical pathology in poultry", Veterinary Record. vol. 102, no. 2, pp. 29-31, 1978.

[12] Farhat, A., and Chavez, E. R. "Comparative performance, blood chemistry, and carcass composition of two lines of Pekin ducks reared mixed or separated by sex", Poultry Science. vol. 79, no. 4, pp. 460-465, 2000.

[13] Huff, G. R., Huff, W. E., Rath, N. C., Anthony, N. B., and Nestor, K. E. "Effects of Escherichia coli challenge and transport stress on hematology and serum chemistry values of three genetic lines of turkeys", Poultry Science. vol. 87, no. 11, pp. 2234-2241, 2008.

[14] Verstappen, F. A., J. T. Lumeij, and R. G. Bronneberg. "Plasma chemistry reference values in ostriches", Journal of Wildlife Disease. vol. 38, no. 1, pp. 154-159, 2002.

[15] Karesh, W.B., Campo, A.D., Braselton, E., Puche, H. and Cook, R.A. „Health evaluation of free ranging and hand reared macaws (Ara spp.) in Peru“, Journal of Zoo and Wild Life Medicine. vol. 28, no. 4, pp. 368-77, 1997.

[16] Ayub Ali, M., Hmar, L., Inaotombi Devi, L., Prava, M., Lallianchhunga, M.C., Tolenkhomba, T.C. „Effect of age on the haematological and biochemical profile of Japanese quails (Coturnix coturnix japonica), International Multidisciplinary Research Journal. vol. 2, no. 8, pp. 32-35, 2012.

[17] Marcinčák, M., Klempová, T., Bartkovský, M., Marcinčáková, D., Zdolec, N., Popelka, P., Mačanga, J., Čertík, M. "Effect of Fungal Solid-State Fermented Product in Broiler Chicken Nutrition on Quality and Safety of Produced Breast Meat”, In BioMed Research International. vol. 2018, Article ID 2609548, pp. 8, 2018.

[18] Duncan, J.R., Prasse, K.W., Mahaffey, E.A. „Veterinary laboratory medicine: clinical pathology“, USA, Iowa State University Press; Ames, Iowa, 1994.

[19] Tietz N.W. „Clinical guide to laboratory tests“, (3rd edn) WB Saunders Company: Philadelphia, 1995.

[20] Onyinyechukwu, A.A., Wilfred, S.E. and Ezinwa, M.I. "The Hematology and Serum Biochemistry Profile of Adult Japanese Quail (Coturnix coturnix japonica)", Notule Scienta Biologicae. Vol. 9, no. 1, pp. 67-72, 2017.

[21] Scholtz, N., Halle, I., Flachowsky, G., Sauerwein, H. "Serum chemistry reference values in adult Japanese quail (Coturnix coturnix japonica) including sex-related differences”, Poultry Science. vol. 88, no. 6, pp. 1186-1190, 2009.

[22] Prakash, R.K. „Serum Biochemical Profile of Japanese Quails (Coturnix coturnix japonica)“, Indian Journal of Fundamental and Applied Life Sciences. vol. 3, no. 1, pp. 182-183, 2013.

[23] Walzem, R. L., R. J. Hansen, D. L. Williams, and R. L. Hamilton. „Estrogen induction of VLDLy assembly in egglaying hens", Journal of. Nutrition, vol. 129, pp. 467-472, 1999.

[24] König, B., H. Kluge, K. Haase, C. Brandsch, G. I. Stangl, and K. Eder. „Effects of clofibrate treatment in laying hens“, Poult. Sci., vol. 86, pp. 1187-1195, 2007.

[25] Lumeij, J.T. "Avian clinical enzymology. Pages 14-24 in Seminars in Avian and Exotic Pet Medicine”, vol. 3. A. M. Fudge, ed. W. B. Saunders Co., Philadelphia, PA, 1994.

[26] Hunt, J. R., and Hunsaker, W. G. "Physiology of the growing and adult goose. 3. Some nitrogen constituents of blood", British Poultry Science. vol. 6, no. 1, pp. 15-21, 1965.

[27] Hassan, H.A. 2010. "Variation in egg performance and plasma constituents at different ages of females Japanese quail”, Egypt. Poultry Science Journal. vol. 30, no. 1, pp. 565-581. 
[28] Brugère-Picoux, J., H. Brugère, I. Basset, N. Sayad, J. Vaast, and J. M. Michaux. "Biochemie clinique en pathologie aviaire. Introit et limites des dosages enzymatiques chez la poule", Revue de Medecine Veterinaire. vol. 163, pp. 1091-1099, 1987.

[29] Harr, K. E. "Clinical chemistry of companion avian species: A review”, Veterinary Clinical Pathology. vol. 31, pp $140-151,2002$.

[30] Lewandowski, A. H., T. W. Campbell and G. J. Harrison. "Clinical chemistries". Pages 192-200 in Clinical Avian Medicine and Surgery. G. J. Harrison and L. R. Harrison, ed. W. B. Saunders Co., Philadelphia, PA, 1986.

[31] Alonso-Alvarez, C., C. Perez, and A. Velando. "Effects of acute exposure to heavy fuel oil from the Prestige spill on a seabird", Aquatic Toxicology. vol. 84, pp. 103-110, 2007.

[32] Lierz, M., and H. M. Hafez. "Sex-related differences in plasma chemistry reference values in stone curlews (Burhinus oedicnemus)", Veterinary Record. vol. 157, pp.91-92, 2005. 